\title{
Physical and chemical characteristics of forest soil in southern Guinea savanna of Nigeria
}

\author{
Chinevu, Christian Nnaemeka', Unanaonwi, Okpo Esio ${ }^{2,}$, Amonum, Joseph Igba ${ }^{3}$ \\ ${ }^{1}$ Department of Science Laboratory Technology, Nasarawa State Polytechnic Lafia, Nigeria \\ ${ }^{2}$ Department of Biological Sciences, Federal University, Otuoke, Bayelsa State, Nigeria \\ ${ }^{3}$ Department of Forest and Forest Productions, Federal University of Agriculture Makurdi, Nigeria
}

\section{Email address:}

Chinevuchristian@yahoo.com (Chinevu C. N.), okpoesio2002@yahoo.com (Unanaonwi O. E.), jamonng@yahoo.com (Amonum J. I.)

\section{To cite this article:}

Chinevu, Christian Nnaemeka, Unanaonwi, Okpo Esio, Amonum, Joseph Igba. Physical and Chemical Characteristics of Forest Soil in Southern Guinea Savanna of Nigeria. Agriculture, Forestry and Fisheries. Vol. 2, No. 6, 2013, pp. 229-234.

doi: $10.11648 /$ j.aff.20130206.15

\begin{abstract}
Most studies on soil characteristics had centered on suitability for agricultural production. Once a soil does not support crop production, it is referred to as poor, unproductive, and finally abandoned. Such soil could be very useful for forest crop plantation. This study was designed to investigate characteristics and describe the forest soil in Ombi, southern Guinea savanna of Nigeria. Soil samples were collected randomly from three locations around the engineering department of Nasarawa State Polytechnic Lafia, at depth of $0-30 \mathrm{~cm}$. Samples $(1 \mathrm{~kg}$ each) were taken in plastics bags to the laboratory for studies. Physical and chemical properties were analyzed according to standard procedures. Results show that sand had the highest $\%$ in soil of the area (74.96). Bulk densities were within the same range $\left(1.68 ; 1.77\right.$ and $\left.1.78 \mathrm{~g} / \mathrm{cm}^{3}\right) \mathrm{for}$ sand, silt and clay respectively. Sand had the highest porosity (37.7\%) while clay had the least (31.6\%). Aggregate stability was least for sand (9.74\%) and highest for clay (56.82\%). Soil reaction was neutral (7.05); nitrogen and CEC were 1.6 and $12.3 \mathrm{Cmol} \mathrm{kg}{ }^{-1}$ among others, while organic carbon was $4.82 \mathrm{~g} / \mathrm{kg}^{-1}$. The soil is described as light and falls under sandy loam. Forest plantation establishment will be worthwhile.
\end{abstract}

Keywords: Forest Soil, Southern Guinea Savanna, Sandy Loam, Forest Plantation

\section{Introduction}

Soil characteristics are made up of two properties namely physical and chemical and a soil will usually behave according to the proportion and organization of these properties. Moreso, the proportion and percentage of the chemical and physical properties of a soil determines the use a soil is put into. Soils are made up of four basic components: minerals, air, water, and organic matter. In most soils, minerals represent around $45 \%$ of the total volume, water and air about $25 \%$ each, and from $2 \%$ to $5 \%$ organic matter [1]. The mineral portion consists of three distinct particle sizes classified as sand, silt, or clay [2,3]. Sand is the largest particle that can be considered soil. Sand is largely quartz, though other minerals are also present. Quartz contains no plant nutrients, and sand cannot hold nutrients as it is easily leached by rainfall or irrigation. Silt particles are much smaller than sand, but like sand, silt is primarily quartz [4].

The smallest of all soil particles is clay. Clays are quite different from sand or silt, and most types of clay contain appreciable amounts of plant nutrients. Clay has a large surface area resulting from the plate-like shape of the individual particles. Sandy soils are less productive than silts, while soils containing clay are the most productive and use fertilizers most effectively [3]. Although farmers, ranchers, foresters, micro-biologists, etc think of soil differently for different purposes, understanding soils and managing them well are essential to human welfare [5].

\subsection{Soil Texture}

Soil texture refers to the relative proportions of sand, silt, and clay [6] and a loam soil contain these three types of soil particles in roughly equal proportions. A sandy loam is a mixture containing a larger amount of sand and a smaller amount of clay, while a clay loam contains a larger amount of clay and a smaller amount of sand [7]. 


\subsection{Soil Structure}

Another soil characteristic is soil structure. Structure refers to the clumping together or aggregation of sand, silt, and clay particles into larger secondary clusters [8,9]. Soil structure is developed through the action of soil biota such as microbes and earthworms. This biota creates openings for water and air penetration and secretes glues and sugars which bind silt and clay particles together to form aggregates [6]. Microorganisms help open up compacted soils so roots can more easily penetrate the soil. Good soil structure is apparent when the soil crumbles easily. This is an indication that the sand, silt, and clay particles are aggregated into granules or crumbs. Both texture and structure determine pore space for air and water circulation, erosion resistance, looseness, ease of tillage, and root penetration [10]. Soil texture is related to minerals in the soil and changes little with agricultural activities. Soil structure on the other hand can be improved or destroyed readily by choice and timing of farming practices. [11]. Soil structure affects aeration, water movement, conduction of heat, resistance to erosion and plant root growth. Water has the strongest effect on soil structure due to its solution and precipitation of minerals and its effect on plant growth.

Soil structure often gives clues to its texture, organic matter content, biological activity, past soil evolution, human use, and the chemical and mineralogical conditions under which the soil formed $[7,12]$.

\subsection{Soil Organic Matter}

Soil organic matter is the component of soil derived from all biological sources-whether living or nonliving. Soil organic matter is a vital indicator of soil health because of its impact on a variety of soil functions and properties. It provides the energy source for micro-organisms in the soil, is a reservoir of nutrients (especially N, P \& S) and improves the structural stability, water holding capacity and $\mathrm{pH}$ buffering capacity of the soil [13].

\subsection{Soil Chemical Properties}

The chemistry of soil determines the availability of nutrients, the health of microbial populations, and its physical properties. In addition, soil chemistry also determines its corrosivity, stability, and ability to absorb pollutants and to filter water. It is the surface chemistry of clays and humus colloids that determines soil's chemical properties. The very high specific surface area of colloids gives soil its great ability to hold and release cations in what is referred to as cation exchange. Cation-exchange capacity (CEC) is the amount of exchangeable cations per unit weight of dry soil and is expressed in terms of milliequivalents of hydrogen ion per 100 grams of soil.

A colloid is a small, insoluble, non-diffusible particle larger than a molecule but small enough to remain suspended in a fluid medium without settling. Most soils contain organic colloidal particles as well as the inorganic colloidal particles of clays [14]. There are over 72 minerals elements present in the soil which are referred to as plant nutrients and are classed as major and minor. They are very essential for plants growth and development. Some of the major elements include carbon, nitrogen, phosphorus, potassium, calcium, magnesium, sulphur, manganese, iron, zinc, copper, boron, and molybdenum [15].

\subsection{Soil Physical Properties}

The physical properties of soils, in order of decreasing importance, are texture, structure, density, porosity, consistency, temperature, color, and resistivity. These determine the aeration of the soil and the ability of water to infiltrate and to be held in the soil. Soil texture is determined by the relative proportion of the three kinds of soil particles, called soil "separates": sand, silt, and clay. Soil density, particularly bulk density, is a measure of soil compaction. Soil porosity consists of the part of the soil volume occupied by air and water. Consistency is the ability of soil to stick together. Soil temperature and colour are self-defining. Resistivity refers to the resistance to conduction of electric currents and affects the rate of corrosion of metal and concrete structures. The properties of the identifiable layers in a particular soil profile may differ [16].

Soil components larger than $2.0 \mathrm{~mm}$ are classed as rock and gravel and are removed before determining the percentages of the remaining components and the texture class of the soil. For example, a sandy loam soil with $20 \%$ gravel would be called gravely sandy loam. When the organic component of a soil is substantial, the soil is called organic soil rather than mineral soil. A soil is called organic if:

(a) Mineral fraction is $0 \%$ clay and organic matter is $20 \%$ or more

(b) Mineral fraction is $0 \%$ to $50 \%$ clay and organic matter is between $20 \%$ to $30 \%$

(c) Mineral fraction is $50 \%$ or more clay and organic matter $30 \%$ or more [16].

Studies on soil characteristics are many a time centered on suitability for agricultural production and once a soil does not support crop production it is referred to as poor, unproductive and degraded. Such soil is usually abandoned. There are other uses that soils could be put into if they are found to be unsuitable for a particular use, thus soil would not be left to lay waste. It is by studying the soil characteristics that would enable right decisions on what types of crop a particular soil can support. This study aims at determining the chemical and physical properties, and as well describes the soil of Ombi 1, Lafia, in the southern Guinea savanna of Nigeria.

\section{Materials and Methods}

\subsection{Study Area}

The study area is Ombi 1 in Lafia North Development Area of Nasarawa State. Nigeria (08.33'N, 08.32'E and $175 \mathrm{~m}$ high). Mean annual rainfall in the area is $1132 \mathrm{~mm}$, minimum and maximum temperature range between $24.8^{\circ} \mathrm{C}$ and $33^{\circ} \mathrm{C}$ respectively. The major occupation in the area is 
farming and the soil is an Oxisol (ferrasol).

\subsection{Soil Sampling}

Soil samples were collected from three locations around the engineering department of Nasarawa State Polytechnic at depth of $0-15 \mathrm{~cm}$ (top soil). Samples ( $1 \mathrm{~kg}$ each) were taken in plastics bags to the laboratory and air dried for studies.

\subsection{Laboratory Analysis}

The Soil properties that were analyzed are: Acidity $(\mathrm{pH})$; EC (Electrical conductivity; Nitrogen $(\mathrm{N})$; Phosphorus $(\mathrm{P})$; Potassium(K); Sodium(Na); Calcium(Ca); Magnesium(Mg); Hydrogen $(\mathrm{H})$; Aluminum( $\mathrm{Al})$; Cation Exchange Capacity(CEC); Organic Carbon(OC); Sand; Silt and Clay.

\subsection{Physical Properties}

Particle size distribution was determined by the hydrometer method as described by [10]. Size distribution of aggregates was measured by wet sieving through a series of sieve $(2.0,1.0,0.5,0.25 \mathrm{~mm})$. Bulk density was determined by core method and total porosity was calculated assuming a particle density of $2.65 \mathrm{~g} / \mathrm{cm}^{3}$.

\subsection{Chemical Properties}

Soil $\mathrm{pH}$ was measured in water (1:1-ratio) using $\mathrm{pH}$ meter. Organic carbon content in the sample was determined by [17] wet-oxidation method. Total nitrogen was determined by the Micro-Kjeldhal digestion- distillation method [18]. Cation exchange capacity (CEC) was determined by saturating $10 \mathrm{~g}$ of soil with normal natural ammonium acetate solution, washing out the excess ammonium with methanol and subsequently distillation the absorbed ammonium into boric solution. The distillate was titrated against standard hydrochloric acid. The exchangeable cations were extracted with $1 \mathrm{M}$ ammonium acetate solution. The extract was then analyzed for calcium $(\mathrm{Ca})$ and magnesium $(\mathrm{Mg})$ by EDTA titration method, and for potassium $\mathrm{K}$ and sodium $\mathrm{Na}$, by flame photometer. Available phosphorus was determined using the Bray No.1 method [19]. Total Aluminum was determined by the method of [20]. Total potassium was determined by flame photometry.

\subsection{Laboratory and Statistical Analyses}

Laboratory analysis was carried out at the Department of Soil Science, Federal University of Agriculture Markudi, Nigeria. Descriptive statistics was used to describe the Laboratory results.

\section{Results}

Result shows that sand has the highest particle size distribution in $1 \mathrm{~g}$ of soil $(74.96 \%)$ while clay particle occupied $17.04 \% / \mathrm{g}$ of soil and the least being silt whose content was $8 \% / \mathrm{g}$ of soil. Bulk densities of the three particles were within the same range but silt was higher than sand by
0.9 and clay higher than silt by 0.10 . Aggregate stability was highest for clay and least for sand.

\section{Discussion}

\subsection{Physical Properties}

The structure and texture of the soil represents the physical properties. Physical property of a soil plays an important role in soil fertility because the amount and sizes of soil particles determine the porosity and bulk density which account for nutrients retention or leaching of nutrients. Result of the study (Table 1) indicated that sand has the highest percentage (74. 96\%) composition in a $1 \mathrm{~g}$ of soil taken from the study area followed by clay particle with $17.04 \%$. The size distribution directly influences the porosity which is highest for sand as is expected because sand is the most porous of the soil particles. Sand has no ability to retain water and good water retention capacity of the soil is an important factor in soil fertility. Clay has the least \% porosity meaning that it has the highest capacity to retain water. This also is one of the reasons why clay particle is referred to as the nutrient storehouse. The high water holding capacity of clay makes it more stable $(56.82 \%)$ than other particles. It is that high stability that enables it to hold nutrient cations for nutrient exchange in the soil for plant uptake. It implies that the higher the clay content of a soil, the higher the cation exchange capacity and the higher the fertility of the soil.

Table 1. Laboratory result of physical properties of soil $(0-15 \mathrm{~cm})$ in $\mathrm{Ombi}$ Area

\begin{tabular}{lllll}
\hline Particle & $\begin{array}{l}\text { \%/g of } \\
\text { soil }\end{array}$ & $\begin{array}{l}\text { Bulk } \\
\text { density }\left(\mathbf{g} / \mathbf{c m}^{3}\right)\end{array}$ & \%porosity & $\begin{array}{l}\text { \%Aggregate } \\
\text { stability }\end{array}$ \\
\hline Sand & 74.96 & 1.68 & 37.7 & 9.74 \\
Silt & 8.0 & 1.77 & 33.2 & 27.51 \\
Clay & 17.04 & 1.78 & 31.6 & 56.82 \\
\hline
\end{tabular}

\subsection{Soil Description}

Heavy and light are commonly used to describe soils. They refer to the easy of tillage, and not to soil weight. Heavy soils are commonly finer soils, which require more horse power because the higher clay content makes them stickier. Light soils have a higher percentage of sand (coarse texture), stick together less, and require less muscle to till. Result of the study (Table 1) has shown that soil of Ombi area of Lafia is light.

\subsection{Soil Chemical Properties}

Chemical properties of soil are made up of elements which are referred to as nutrients in plant nutrition. These elements affect yield of forest trees in one way or the other. These elements are divided into macro and micro nutrients. The macro-nutrients are required in large amount by plants for optimum growth and yield while the micro-nutrients are required in small quantity by crop. 


\subsection{Acidity}

In relation to yield, soil acidity is the power house for plant nutrients [21]. Soil acidity results to complex change in the soil, such as increase in toxic levels of aluminum, inhibition of microbial processes, reduction of the cation exchange capacity and reduced availability of soil phosphorus. The inability of crops to utilize water effectively and take up sufficient quantities of nutrients is often the most visible problem with soil acidity. Acids soils are deficient of key macro nutrients such as calcium, magnesium and potassium. High soil acidity therefore will result into decrease in root growth and will therefore not favour tuber crops. Laboratory results (Table 2) shows that Ombi soil has acidity level of 7.05 indicating that the soil is not acidic but neutral. The result shows an increase acidity level of 0.85 from that of the Northern Guinea savanna of Nigeria [21]. The fact that the major crops cultivated in the area are tubers, as in other parts of Nasarawa State, further supports this result.

Table 2. Laboratory result of chemical properties of soil $(0-15 \mathrm{~cm})$ in $\mathrm{Ombi}$ Area

\begin{tabular}{lll}
\hline Chemical property & Unit & Amount \\
\hline Acidity (pH) & $(1: 1) \mathrm{H}_{2} \mathrm{O}$ & 7.05 \\
Electrical conductivity (EC) & $\mathrm{Ms} \mathrm{m}^{-1}$ & 812.0 \\
Nitrogen (N) & $\mathrm{Cmol} \mathrm{kg}^{-1}$ & 1.60 \\
Phosphorus (P) & $\mathrm{Cmol} \mathrm{kg}^{-1}$ & 2.60 \\
Potassium (K) & $\mathrm{Cmol} \mathrm{kg}^{-1}$ & 0.95 \\
Sodium (Na) & $\mathrm{Cmol} \mathrm{kg}^{-1}$ & 1.64 \\
Calcium (Ca) & $\mathrm{Cmol} \mathrm{kg}^{-1}$ & 12 \\
Magnesium (Mg) & $\mathrm{Cmol} \mathrm{kg}^{-1}$ & 3.81 \\
Hydrogen (H) & $\mathrm{Cmol} \mathrm{kg}^{-1}$ & 3.60 \\
Aluminum (Al) & $\mathrm{Cmol} \mathrm{kg}^{-1}$ & 0.70 \\
Cation Exchange Capacity (CEC) & $\mathrm{Cmol} \mathrm{kg}^{-1}$ & 12.3 \\
Organic Carbon (OC) & $\mathrm{g} \mathrm{kg}^{-1}$ & 4.82 \\
\hline
\end{tabular}

\subsection{Nitrogen}

Soil nitrogen for the study area is $1.60 \mathrm{Cmol} \mathrm{kg}^{-1}$. [ 22] reported $1.45 \mathrm{Cmol} \mathrm{kg}^{-1}$ for the Northern Guinea savanna of Nigeria. Nitrogen accounts for up to $3 \%$ of all plant compounds. It is the most abused and misused production input in growing crops. The key to reducing nitrogen growing costs is to reduce nitrogen losses. The present nitrogen recommendations in most growing situations are based upon experience and are usually in excess of specific plant requirements. Nitrogen losses come about by reduced aeration and higher compaction in soil. Nitrates can be lost by being converted to gaseous nitrogen by anaerobic soil microorganisms in soils. The losses from gasification will be more on heavy soils than on light-textured soils. Leaching losses of nitrogen will be higher on light soils. Excess amounts of nitrogen can destroy soil humus and tilt. When excessive nitrogen is present in the soil, microorganisms will multiply by attacking the carbonaceous humus that is more accessible than randomly distributed crop residue. By breaking down humus for their carbon needs, soil microbes can deplete the humus reserve in soil. This depletion reduces the stable humus aggregates that are vital to tilt and aeration of a healthy soil and will subsequently affect crop yield. Crop requires nitrogen for formation of tuber, seed and healthy crop stand.

\subsection{Phosphorus}

Laboratory result shows that 1 kilogram of soil in the study area has $2.60 \mathrm{Cmol}$ of Phosphorus. When phosphorus intake is deficient, plants will produce red and purple leaf colors and exhibit stunted root and top growth. Most synthetic phosphate fertilizers, when added to the soil, undergo a degree of phosphate fixation with other soil elements. The degree of fixation depends upon the chemical nature of the soil. High sodium levels reduce phosphorus availability. Bioorganic phosphates are chelated in organic complexes and designed to favour microbiological activity that converts phosphorus to a more available form for crop use, thereby, preventing losses by fixation.

\subsection{Potassium}

Plants contain an average of about $3 \%$ potassium as a part of plant tissue. Potassium is essential in the translocation of vital sugars in plant structures, strengthening plant stalks. Conventional fertilizers such as muriate of potash or potassium chloride are salts and contain chloride just as table salt (sodium chloride) does. Plants use potassium as the element $\mathrm{K}^{+}$ion and its availability depends upon its position within the soil and relationship to clay, humus and soil water. A clay particle is a strong magnet in comparison to sand, silt and humus. Clay soils hold potassium very tightly and resist leaching. This characteristic makes it more difficult to recover potassium from clay soils. Soil aeration and healthy, balanced aerobic microbial activity are essential for making potassium available to plant. Soil of the area in this study has $0.95 \mathrm{Cmol} \mathrm{kg}^{-1}$ potassium.

\subsection{Calcium}

Soil calcium level in the study area is $12 \mathrm{Cmol} \mathrm{kg}^{-1}$. Calcium is often called the prince of nutrients because the soil colloid has to have a great saturation of calcium for plant uptake. It accounts for about $2 \%$ of plant tissue. Calcium is used to make calcium pectate, a sturdy building material component of cell walls. Calcium deficiency causes stunted roots and stress symptoms in new leaves and discoloration and distortion of plant growth. It may be the single most important soil and plant element. However, [22] reported a significant negative correlation between calcium and gum yield in soil of the northern guinea savanna of Nigeria. 


\subsection{Magnesium}

Chlorophyll molecule is built around a single atom of magnesium, which accounts for about $1 \%$ of plant tissue. Magnesium deficiency causes poor photosynthesis that restricts plant growth and vitality. Soil of Ombi has magnesium value of $3.81 \mathrm{Cmol} \mathrm{kg}^{-1}$.

\subsection{Cation Exchange Capacity}

Table 2 shows that CEC in soil of the study area was $12.3 \mathrm{Cmol} \mathrm{kg}^{-1}$. The cation exchange capacity is a value given in soil analysis report to indicate its capacity to hold cation nutrients. It is determined by amounts of clay and humus that are present in a soul. These two colloidal substances are essentially the cation warehouse or reservoir of the soil and are very important because they improve the nutrient and water holding capacity of the soil. Sandy soils with little organic matter have a low CEC, but clay soils with high levels of organic matter, would have a much greater capacity to hold cations. A soil with low CEC has little or no clay or humus content. It cannot hold much water or cation nutrients and therefore, forest crop would not grow well in them.

\subsection{Organic Carbon}

Result indicated that the organic carbon content of soil in Ombi is $4.82 \mathrm{~g} \mathrm{~kg}^{-1}$. Soil organic carbon is directly related to soil fertility in that it is the organic carbon present in soil that is eventually converted to nitrate for plant uptake [5]. This implies that the more the organic carbon contents of a soil, the more the nitrogen content of the soil, and the more fertile the soil will be.

\section{Conclusion}

The aim of this study was to determine the chemical and physical properties and to describe the soil of Ombi area. The investigation has shown from laboratory analysis that some of the trace elements such as Boron, Zinc, Copper and Iron were not present in the soil of the area. Sand has the highest percentage in the soil of the area while silt was the lowest. Soil of the area can be described as light with its higher $\%$ of sand. Soil of the area is good for the cultivation of tuber crops as is presently the case in the area, because of its low or neutral soil reaction. Forest trees would therefore thrive well. Plantation establishment of tree crops is recommended.

\section{References}

[1] G.J. Retallack, 2008. Soils of the Past: An Introduction to Paleopedology (2 ed.). John Wiley and Sons. 2008, pp. 207. UK.

[2] S.W.Boul, Soil genesis and classification, Ames, Lowa: Lowa State University Press, 1990, pp. 36, doi:10.1081/E-ESS.

[3] H.B. Milford; E.J.A. McGaw, K.J. Nixon, Soil Data Entry
Handbook for the NSW . Soil and Land Information System (SALIS), 3rd ed., New South Wales Department of Land and Water Conservation Resource Information Systems Group, Parramatta, 2001, pdf pp. 30-32.

[4] O.E.Unanaonwi, Acidity, Organic carbon and Nitrogen status of soils under Acacia senegal L. (Willd.) Plantation and Natural forest in Gummi forest reserve, Zamfara State, Nigeria. Nigerian Journal of Forestry, 2009c ,Vol.38 (2): 9199 .

[5] R. Micheal, Factors Affecting Soil Development, Soil Systems, The Physical Environment: an Introduction to Physical Geography, University of Wisconsin, Stevens Point, October 1, 2009, retrieved January 3, 2012.

[6] A. James, The Terrestrial Influence: Geology and Soils. Columbia University, 2008, pp46.

[7] R. Janet, Dirt Is Not Soil. ScienceNews, July 17th, 2008.

[8] R. P. Voroney, The Soil Habitat. Soil Microbiology, Ecology and Biochemistry, Eldor A. Paul (ed). 2006, 12-546807-5

[9] ASA., 2005. American Society of Agronomy.www.agronomy.org Retrieved $28^{\text {th }}$ October,2012.

[10] R.B. Brown, "Soil Texture" .Fact Sheet SL-29. 2003, University of Florida, Institute of Food and Agricultural Sciences.

[11] D. E. Baker., V.J. Eldershaw, Interpreting soil analyses - for agricultural land use in Queensland. Dept. of Primary Industries, Project Report Series, 1993, QO93014, Australia.

[12] R. Lines-Kelly, Soil Sense Soil Management for NSW North Coast Farmers. NSW Agriculture, Wollongbar, 1994, NSW, Australia.

[13] Soils., Yearbook of agriculture. Alfred Sefferud. ed. , The United States Department of Agriculture 1957, pp. 17.

[14] IUSS Working Group WRB, "World Reference Base for soil resources - A framework for international classification, correlation and communication", 2007, FAO, Rome.

[15] Soils, An Introduction to Soils and Plant Growth. Prentice Hall Inc. 1977, pp. 101-102.

[16] A. Walkey; I.A. Black, 1934. Soil Science. 37: 29-38.

[17] M.A. Bremner, Total nitrogen. In Methods of soil analysis part 1. (Ed) BLACK, C.A. 1965, American Society of Agronomy. Monograph No.9. pp371.

[18] R.H.Bray; L.T. Kurtz, Determination of total organic and available forms of phosphorus in soils. Soil Sc. 1945, 59:3945 .

[19] F. Liu, Handbook on Environment Monitoring for Agriculture. China Standard Press, Beijing, 2001, Pp 699.

[20] ASA. American Society of Agronomy, 1971, www.agronomy.org Retrieved $28^{\text {th }}$ October, 2012.

[21] O.E.Unanaonwi, Effects of nitrogen, calcium and cation exchange capacity on gum yield in Acacia senegal under plantation and savanna woodland conditions in northern Guinea savanna, Nigeria. iForest 2011, 4:190-194 \{online 2011-08 11\}URL:http://www.sisef.it/iforest/show.php?id=587 
[22] O. E. Unanaonwi Relationship between gum yield and soil chemical properties under natural stands of Acacia senegal L. Journal of Research in Agriculture. 2009b, Vol.6 (4): 79-83. 